\title{
THE EFECTIVENESS OF USING AUTHENTIC READING MATERIALS TOWARD STUDENTS' READING COMPREHENSION MASTERY
}

\author{
Diyah Dwi Agustina ${ }^{1}$, Adelina Anum ${ }^{2}$ \\ ${ }^{1}$ University of Nahdlatul Ulama Lampung,Indonesia ${ }^{2}$ University of Saburai Lampung, \\ Indonesia. \\ e-mail: ${ }^{1}$ diyahdwiagustina348@gmail.com, ${ }^{2}$ punya.adel@gmail.com
}

\begin{abstract}
A difficult reading material has become one of the student problems in comprehending the text. The application of using Authentic Reading Materials is needed for students. In the university level, the students have some difficulties in reading comprehension. This case is no exception for students in English Education Department of Nahdlatul Ulama Lampung University (UNU Lampung). The students of sixth semester got the Reading course for 3 credits semester. This research aims to know the effectiveness of using Authentic Reading Materials towards the students reading comprehension mastery. This experimental research used quantitative method and queasy experimental design. The research conducted at the sixth grade of English Education Department of Nahdlatul Ulama Lampung University which has the population 8 classes. The sample used in this research is 20 students as experimental class and 20 students as control class. The researcher uses purposive sampling as technique sampling. Based on the result of $T$ test formula, $t_{\text {ratio }}$ is 4,61 and $t_{\text {table }}$ is 2,44 . It means that $t_{\text {count }}>t_{\text {table. }}$. The result of this research indicates that using Authentic Reading Materials is effective towards the students reading comprehension mastery at the sixth grade of English Education Department of Nahdlatul Ulama Lampung University
\end{abstract}

Keywords—authentic materials, reading comprehension

\section{INTRODUCTION}

In 2021 the development of teaching and learning uses high technology works rapidly. In Indonesia, the position English is used as the foreign language. Most of countries in the world use English as the communication language. That is the reason why English is used in many aspects, especially in economic and education. Because of that, every student from elementary school up to the university level should study English as foreign language.

Nowadays, teachers of English as a foreign language instinctively know that students' vocabulary acquisition is fundamental to mastery of a foreign language (Syafrizal et al., 2019). An essential contribution to reading comprehension is building oral language skills (vocabulary in reading comprehension of extended discourse forms. Reading integrates visual and non visual information. During the act of reading, the visual information found on 
the page combines with the non visual information contained in your head to create meaning (Dhilon, 2020). In teaching learning English as foreign language needs skills and competences. The four language skills are listening, writing, reading, and speaking. Then, the components of English are phonetic, vocabulary, and grammar. English as Foreign Language (EFL) context, reading has been a part of skills which is needed to master the language since it helps the EFL students to enrich vocabularies and learns how to create sentences.

In the university level, the students have some difficulties in reading comprehension. This case is no exception for students in English Education Department of Nahdlatul Ulama Lampung University (UNU Lampung). The students of sixth semester got the Reading course for 3 credits semester. Based on the observation in the sixth grade of English Education Department, it shows that the most of the students not interested to English subject. Most of them got some problems such as comprehending the text, drawing the conclusion and finding the details of the text. They also have lack of vocabulary and grammar mastery. They also have low motivation and interest in reading. In the same line, they had lack of vocabulary. It makes the students were difficult to find the closets meaning of the words. Finally, the students got low achievement in reading comprehension. From these problems, the researcher tried to use Authentic Reading Materials in order to solve the problem.

Reading is one of the two receptive skills after listening (Haerazi et al., 2019). Reading comprehension is the ability of the reader to recite the contents of the argumentation, expository, or read a description of a particular topic (Martina et al., 2020). Some students perceive that reading is a boring activity. The boredom can lead the students to have low motivation in doing the reading activity (Handayani et al., 2019). The development of reading skills and reading habits is not limited to childhood or early adolescence; rather, it is a lifelong process (Locher \& Pfost, 2020). Teachers must provide as many as possible materials with relevant contexts for their student (Rusmawaty et al., 2018). It is believed that authentic materials are able to stimulate students' motivation to learn. They can support students' opportunities to intermingle with real uses of language rather than artificial materials which are made for learning purposes only (Rusmawaty et al., 2018). Teaching strategies in reading comprehension are important in the learning process and could affect the students reading comprehension(Enggar Wigawati Wibowo et al., 2020).

In addition, Jacobson says that while text type is an important consideration when assessing materials, just as important is how those materials are used (Dilek Belet Boyaci \& Güner, 2018). The following examples demonstrate that real life materials can be used in either authentic or schoolonly ways. Likewise statement above about Authentic Materials, according to Larsen and Freeman, the teacher uses a real newspaper article, assigns the students homework requiring that they listen to a live radio or television broad cast (Ibrahim Magableh \& Abdullah, 2020). Authentic materials can be found in our life for instance, newspaper, television, radio, magazine, and also many 
things as real example in our real life. Using Authentic Reading Materials gave ideas for the students to explore their ability in English.

The previous researches show the use of Authentic Reading Materials. The first case study design from Sukmawan and Setyowati shows that Authentic Reading Material were use for reading to write the students voice (Sukmawan \& Setyowati, 2019). Therefore, The second study from Rusmawaty believed that authentic reading materials can link students to contextual use of English, as they can improve students' communicative and cultural competences (Rusmawaty et al., 2018). The study revealed that three themes of teachers' beliefs emerged, (1) types of authentic reading materials, (2) skills to be improved after reading, and (3) teachers' challenges of using authentic reading materials for the classroom- bases. The third study entitled The Impact of Authentic Material Use on Development on Reading Comprehension, Writing skills and Motivation in Language Course explain that found that students who participated in the study had positive views on the Turkish language course instructed with authentic task-based authentic material (Dilek Belet Boyaci \& Güner, 2018). The researcher assumes that Authentic Reading Materials were use for some cases. After state the art of previous research survey, the researcher focused on the effectiveness of using Authentic Reading Materials toward the students reading comprehension mastery.

The Hypothesis of this research as follow:

Ho : Authentic Reading Materials is not effective toward student's reading comprehension mastery at the sixth grade of English Education Department of Nahdlatul Ulama Lampung University.

Ha : Authentic Reading Materialsis effective toward student's reading comprehension mastery at the sixth grade of English Education Department of Nahdlatul Ulama Lampung University.

\section{RESEARCH METHODOLOGY}

The researcher used queasy experimental design. In this research, the researcher chose Non Equivalent Control Group (Non Randomized Control Group Pretest-Post test Design). The design is as follow:

Table 1. The design of the research

\begin{tabular}{cccc}
\hline $\mathrm{E}$ & $\mathrm{O} 1$ & $\mathrm{X} 1$ & $\mathrm{O} 2$ \\
$\mathrm{C}$ & $\mathrm{O} 2$ & $\mathrm{X} 2$ & $\mathrm{O} 2$ \\
\hline
\end{tabular}

Note:

$\mathrm{E}=$ Experimental Class

$\mathrm{C}=$ Control Class 


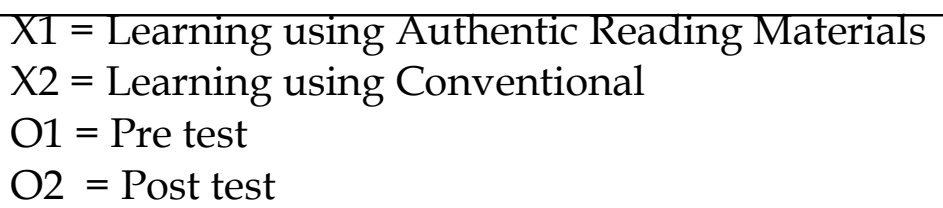

Here, the independent variable is Authentic Reading Materials $(X)$ and dependent variable is Reading Comprehension $(\mathrm{Y})$. The researcher conducted the research on Jan-June 2021 in University of Nahdlatul Ulama Lampung. University of Nahdlatul Ulama Lampung is located in Jl. Raya Lintas Timur Pantai Sumatra, East lampung. The population shows as follow:

Table 2. The population of English Education Department of University of Nahdlatul Ulama Lampung

\begin{tabular}{lll}
\hline No & Class & Total \\
\hline 1 & PBI 2 A & 20 \\
\hline 2 & PBI 2 B & 20 \\
\hline 3 & PBI 4 A & 20 \\
\hline 4 & PBI 4 B & 20 \\
\hline 5 & PBI 6 A & 20 \\
\hline 6 & PBI 6 B & 20 \\
\hline 7 & PBI 8 & 17 \\
\hline 8 & PBI 8 & 13 \\
\hline Total of Student & 150
\end{tabular}

Source: The central information of University of Nahdlatul Ulama Lampung

The researcher took the sample by using purposive sampling because the sample is selected based on the characteristic of a population and the purpose of the study, PBI A as control class and class PBI B as experimental class.

\section{Research Instrument}

The researcher gave try out to know whether the question test valid and reliable or not to be pre-test and post test. The number of questions in try out is 65 questions. After knowing the reliability, the researcher administers pre test before treatment. Then, the researcher administers post test after giving treatment. The type of instrument test is multiple choices.

Table 3. Specification table instrument of reading comprehension mastery

\begin{tabular}{lllll}
\hline \multirow{2}{*}{ No } & \multirow{2}{*}{ Indicator } & \multicolumn{2}{c}{ Items } \\
\cline { 3 - 4 } & \multirow{2}{*}{\begin{tabular}{c} 
Kind of \\
\cline { 3 - 4 }
\end{tabular}} & test & \multicolumn{2}{c}{ Item test } \\
\hline 1 & $\begin{array}{l}\text { Determine main idea } \\
\text { (topic). }\end{array}$ & $\begin{array}{l}\text { Multiple } \\
\text { choice }\end{array}$ & $1,3,6,17,21,26$ & $1,9,13,18,21,26$ \\
\hline
\end{tabular}


2 Determine the inferences. Multiple $2,5,8,9,22,27 \quad 2,8,15,19,22,27$ choice

\begin{tabular}{llll}
\hline 3 & $\begin{array}{l}\text { Determine unstated } \\
\text { details. }\end{array}$ & $\begin{array}{l}\text { Multiple } \\
\text { choice }\end{array}$ & $\begin{array}{l}12,13,15,18,23,4,7,17,20,23,28 \\
28\end{array}$ \\
\hline 4 & $\begin{array}{l}\text { Determine details of } \\
\text { descriptive. }\end{array}$ & $\begin{array}{l}\text { Multiple } \\
\text { choice }\end{array}$ & $4,10,14,19,24,293,5,14,16,24,29$ \\
\hline 5 & $\begin{array}{l}\text { Determine the vocabulary } \\
\text { in context. }\end{array}$ & $\begin{array}{l}\text { Multiple } \\
\text { choice }\end{array}$ & $\begin{array}{c}7,11,16,20,25,306,10,11,12,25, \\
30\end{array}$ \\
\hline
\end{tabular}

\section{Validity and reliability of the instrument}

The researcher did the try out using 30 samples. Then the result is analyzed. The formula of validity like as bellow:

$$
\mathrm{rxy}=\frac{\mathrm{n} \Sigma \mathrm{XX} \mathrm{Y}-(\mathrm{NX})(\Sigma \mathrm{Y})}{\sqrt{\left(\mathrm{n} \Sigma \mathrm{X}^{2}-(\Sigma \mathrm{X})^{2}\right)\left(\mathrm{N} \cdot \Sigma \mathrm{Y}^{2}-(\Sigma \mathrm{Y})^{2}\right)}}
$$

With test criteria:

If $r$ count $\geq$ than $r$ table, so refused Ho, it means that valid variable.

If $r$ count $\leq$ than $r$ table, so receive Ho, it means that not valid variable.

(Yani et al., 2011)

Then the researcher analyzes the data using Spearman Brown (Split Half) formula. The procedure as follows:

The researcher divided the valid item in half. Correlate the sets of scores (total score of up gap and bottom gap), to find coefficient correlation of test the researcherused "Pearson product moment formula"(Yani et al., 2011) as follows:

$$
r x y=\frac{n \sum X Y-(\Sigma X)(\Sigma Y)}{\sqrt{\left(n \Sigma X^{2}-(\Sigma X)^{2}\right\}\left\{N \cdot \Sigma Y^{2}-(\Sigma Y)^{2}\right\}}}
$$

Note:

rxy $=$ Coefficient correlation Pearson Product-Moment

$\mathrm{n}=$ The number of students

$\square=$ Sum

$X=$ The students total score from up gap

$\mathrm{Y}=$ The students total score from bottom gap

Apply the Spearman-Brown correction formula to find the reliability test. The formula is as follow:

$$
\begin{aligned}
& \text { r11 }=\frac{2 \times r_{x y}}{\left(1+r_{x y}\right)} \\
& \text { Note: } \\
& \text { r11 = Reliability of instrument } \\
& \text { rxy = Correlation between score each split }
\end{aligned}
$$


Evaluating the result. The result of r11 consulted to the criteria of reliability as follows:

Reliability coefficient

A very high reliability ranges from 0.81 up to 1.00

A high reliability ranges from 0.61 up to 0.80

Average reliability ranges from 0.21 up to 0.60

A very low reliability rages from 0.00 up to 0.20

\section{Data Collecting Technique}

The researcher gave the pre test for experimental and control class which is multiple choices consisted of 30 questions. The students must do the test in 60 minutes. After giving Treatment, the researcher gave the post test. The instrument of post test is equivalent with Pre Test. At the end, the researcher gave the post test for experimental and control class. The kind of the test is multiple choices. The kind of the test is multiple choices. The tests consist of 30 questions including noun, verb, adverb, adjective, and pronoun. The students must do the test in 40 minutes. Therefore the researcher got the data from Post Test.

\section{Data Analysis Technique}

The researcher uses T-test formula.

Normality test

The purpose of normality test is to know whether data distribution is normal or not. In statistic, normality test are used to determine whether the data set is well modeled by a normal distribution or not. The researcher used Chi Square formula. In normality test, the researcher finds out each score of distribution of Expected Frequency and Perception Frequency. The formula of Chi Square is as follow:

$$
\begin{aligned}
& X 2 \text { ratio }=\sum \frac{\left(O_{i}-E_{i}\right)^{2}}{E_{i}} \\
& \text { The criteria of testing } \\
& \text { Received Ho if } x 2 \text { ratio } \leq x 2 \operatorname{table}(I-a),(k-3)
\end{aligned}
$$

\section{Homogeneity test}

Homogeneity is a measurement used to determine data variety. The researcher used $\mathrm{F}$ table formula. The formula of homogeneity test is as follow:

Fratio $=\frac{\text { the bigest variance }}{\text { the smallest variance }}$

The criteria of testing

Reject Ho if Fratio $\geq F 1 / 2$ a (v1 . v2)

Hypothesis test

After the researcher knows that the data distribution is normal and homogeneous, the test is continued to the hypothesis test. Some steps of hypothesis test as follow:

Formula of hypothesis 
Ho $=\mu 1=\mu 2$

$\mathrm{Ha}=\mu 1 \neq \mu 2$

Statistic formula

If $\sigma 1=\sigma 2=\sigma$, and $\sigma$ is unknown, the statistic is :

Tratio $=\frac{X_{1}-X_{2}}{\sqrt[5 g]{\frac{1}{n_{1}}+\frac{1}{n_{2}}}}$

Note:

$X=$ Mean

$\mathrm{S}=$ Variant

$\mathrm{n}=$ number of Students

Where: $S_{\mathbf{g}}^{2}=\frac{\left(n_{1}-1\right) S_{1}^{2}+\left(n_{2}-1\right) S_{2}^{2}}{n_{1}+n_{2}-2}$

The testing criteria received Ho if $-\mathrm{tdaf}<\mathrm{thit}<\mathrm{tdaf}$

Where $\mathrm{tdaf}=\mathrm{t}(1-1 / 2 \mathrm{\alpha})(\mathrm{n} 1+\mathrm{n} 2-2)$

The criteria are:

- Ho : is accepted if $\mathrm{t}$-ratio is equal or lower $\mathrm{t}$-table (the hypothesis proposed is not proved)

- Ha : is accepted if t-ratio is equal or higher than $\mathrm{t}$-table (the hypothesis proposed is proved)

The data analyzing of gain normalization test is used for hypothesis test. The formula is:

$$
<g>=\frac{T_{2}-T_{1}}{T_{M A X}-T_{1}}
$$

Note :

$\mathrm{T} 1=$ score pre test

T2 = score post test

Tmax = score maximum ideal

\section{Hypothesis statistic}

- Ho: $\mu 1=\mu 2$ (Authentic Reading Materials is not effective toward student's reading comprehension mastery at the sixth grade of English Education Department of Nahdlatul Ulama Lampung University).

- На : $\mu 1 \neq \mu 2$ (Authentic Reading Materialsis effective toward student's reading comprehension mastery at the sixth grade of English Education Department of Nahdlatul Ulama Lampung University). 


\section{RESULT AND DISCUSSION}

\section{Validity and reliability}

The researcher did the try out using 30 students as the sample. The researcher gave the try out consist of 65 items of instrument. After got the data, the researcher was tabulate the data and correlated the item score of instrument in a factor. Therefore, the researcher was correlate factor score and total score. Finally there are 60 valid items which are divided into pre test and post test .

There are 5 items which are invalid out of 65 items. So, there is 60 valid items. It is because $r_{\text {count }} \geq$ than $r_{\text {table, }}$ so refused Ho, it means that valid variable. it is fine for $\mathrm{r}$ table $5 \%(0,233)$ and $\mathrm{r}$ table $1 \%(0,3170)$. Therefore, there are 60 items are valid. In this research, the researcher used the valid item of instrument for pre test and post test. Finally, the researcher used 40 items for pre test and post test.

After calculating the data by using Product Moment Formula, the result is 0,762 in the try out test. There is the correlation between first and second items score and from the calculation that by using Spearman Brown, the result has high interpretation. So, the test is valid and reliable.

\section{The result of data collecting technique}

In this research, the researcher gave pre test before the treatment. The researcher administered the pre-test for experimental class and in control class. The researcher gives pretest to 20 students in experiment class and 20 students in control class. In experimental class the highest score is 75 and the lowest is 40 with average score is 51. Meanwhile, in control class the highest score is 70 and the lowest score is 45 with the average 52. Based on the data, it shows that the most of students have low mastery in reading comprehension.

In this research, the researcher gave 8 treatments, and each treatment consists of some different topics depend on the materials. Based on the result of daily score in each meeting, it is obtained that the average score in experimental class for the first until meeting is 54 , for the second meeting is 60 , for the third meeting is 67 and for the fourth meeting is 73 . And then, the result of daily score in experimental class is obtained that the average score for the first meeting is 56,6 , for the second meeting is 58 , for the third meeting is 64 and for the fourth meeting is 67. In the conclusion, the average of daily score in experimental class is higher than the average of daily score in control class.

Based on the result of post test in control class, it is obtained the highest score is 85 and the lowest score is 60 with average 75. Meanwhile, in control class the highest score is 80 and the lowest score is 45 with average 62,8 .

Data analysis technique

The result of data analysis techniques as bellows:

The result of normality test

The normality is done to know whether that test come from the population that had the normal distribution or not. The data normality of the 
test accepted Ho if $x_{h i t}^{2} \leq \underline{x}_{d a f}^{2}$ for the significant level $5 \%(\alpha=0.05)$ and also the significant level 1\% ( $\alpha=0.01)$.For further description, can be seen as follow:

Table 4 . The data result of normality distribution of post test

\begin{tabular}{|c|c|c|c|c|c|}
\hline \multirow{3}{*}{ Test } & \multirow{3}{*}{$\begin{array}{c}\text { Variable } \\
(\mathrm{X})\end{array}$} & \multirow{3}{*}{$\mathrm{X} 2$ ratio } & \multicolumn{2}{|c|}{$\mathrm{X} 2 \mathrm{df}$} & \multirow{3}{*}{ Conclusion } \\
\hline & & & \multicolumn{2}{|c|}{ Significance Level } & \\
\hline & & & $\begin{array}{c}5 \% \\
(\alpha=0,05)\end{array}$ & $\begin{array}{c}1 \% \\
(\alpha=0,01)\end{array}$ & \\
\hline \multirow[t]{2}{*}{ Pre test } & $\mathrm{X} 1$ & 3,54 & 7,81 & 11,3 & Normal \\
\hline & $\mathrm{X} 2$ & 3,12 & 7,81 & 11,3 & Normal \\
\hline \multirow[t]{2}{*}{ Post Test } & $\mathrm{X} 1$ & 3,57 & 7,81 & 11,3 & Normal \\
\hline & $\mathrm{X} 2$ & 3,21 & 7,81 & 11,3 & Normal \\
\hline
\end{tabular}

Source: The data result of normality distribution of post test in experimental class and control class

Note:

$\mathrm{X} 1 \quad$ : Experimental class

X2 : Control class

Based on the table above, it is obtained that that X2ratio pre test data and post test data is lower than X2daf (L-table) in both of the significant level 5\% (a $=0.05)$ and $1 \%(\alpha=0.01)$. So, the hypothesis Ho is accepted. It means that both samples in this research come from the normal distribution of population.

\section{The result of homogeneity test}

Based on the calculation of normality test, the population of the data came from normal distribution. So, the researcher also conducted the homogeneity variance from both sample to prove whether both sample have the variance equality or not. The data of homogeneity test accepted if fratio $<$ ftab. The criteria of homogeneity test are:

- Ho = F-ratio is lower than F-table (the variance of the data are homogeneous).

- $\mathrm{Ha}=$ F-ratio is higher than F-table (the variance of the data are not homogeneous).

The description of homogeneity test can be seen by following table:

Table 5. The data result of homogeneity test

\begin{tabular}{|c|c|c|c|c|}
\hline \multirow{3}{*}{ Test } & \multirow{3}{*}{ F-ratio } & & & \multirow{3}{*}{ Conclusion } \\
\hline & & \multicolumn{2}{|c|}{ Significance Level } & \\
\hline & & $\begin{array}{c}5 \% \\
(\alpha=0,05)\end{array}$ & $\begin{array}{c}1 \% \\
(\alpha=0,01)\end{array}$ & \\
\hline Post test & 1,6246 & 2,30 & 1,80 & Homogeneous \\
\hline
\end{tabular}


From the table, it is obtained that fratio post test is lower than $\mathrm{ftab}$ in the significance level of $5 \%(a=0,05)$ and $1 \%(a=0,01)$. In short, hypothesis Ho accepted means that both samples of the population have same variance or homogeneous.

\section{The result of hypothesis test}

After giving the test and getting the result data of the test, the researcher used quantitative analysis in order to prove the hypothesis that there is significant influence of using Authentic Reading Materials toward the students' reading comprehension mastery at sixth grade of University of Nahdlatul Ulama Lampung. In analyzing the result data of post test, the researcher used the formula Ttest. The researcher had formulated the Alternative Hypothesis as follows:

Using Authentic Reading Materials is effective toward the students' reading comprehension mastery at the sixth grade of University of Nahdlatul Ulama Lampung in in 2021. The criteria for this hypothesis is accepted Ha if $\mathrm{t}$ ratio $>\mathrm{t}$-table at the certain level of significant, in this case the researcher uses 0,05 . The calculation of the hypothesis testing was shown in table presented as follow:

Table 6 . The data result of hypothesis 1

\begin{tabular}{|c|c|c|c|c|c|c|c|}
\hline \multirow{2}{*}{ Variable } & \multirow{2}{*}{$\begin{array}{c}X \\
\text { Post test }\end{array}$} & \multirow{2}{*}{ S12 } & \multirow{2}{*}{ S22 } & \multirow{2}{*}{ t-ratio } & \multicolumn{2}{|c|}{ t-table } & \multirow{2}{*}{ Conclusion } \\
\hline & & & & & $5 \%$ & $1 \%$ & \\
\hline $\mathrm{X} 1$ & 75 & \multirow{2}{*}{38,94} & \multirow{2}{*}{66,46} & \multirow{2}{*}{4,61} & \multirow{2}{*}{2,00} & \multirow{2}{*}{2,66} & \multirow{2}{*}{ Significant } \\
\hline $\mathrm{X} 2$ & 62,8 & & & & & & \\
\hline
\end{tabular}

Source: The data result of hypothesis test in experimental class and control clasS

Note:

$\mathrm{X} 1 \quad$ : Experimental class

X2 : Control class

According to the table above, it showed that $t$-ratio $>\mathrm{t}$-table in significant level 0,05 was 2,00. So, it could be conclude that Ho was rejected and Ha was accepted. It means that, there was difference influence of using Authentic Reading Materials toward the students' reading comprehension mastery at the sixth grade of University of Nahdlatul Ulama Lampung in in 2021.

It also concluded that the students' reading comprehension mastery was taught using Authentic Reading Materials was higher than using conventional teaching materials. So, Authentic Reading Materials was effective for students' reading comprehension mastery at the sixth grade of University of Nahdlatul Ulama Lampung in 2021.

\section{Discussion}

In this research, in experimental class and control classes were treated for four meetings. The researcher gave treatment using Authentic Reading Materials. The researcher taught control class using Authentic Reading 
Materials. The data which was described in this research was the data of the influence of using Authentic Reading Materials in reading comprehension mastery at the sixth grade of University of Nahdlatul Ulama Lampung. Based on the result of this research, the researcher finds that students' reading comprehension mastery in experimental class is better than control class. It can be proven that there are many students in control class got lower score than in experimental class.

In the reality, the teacher gave the conventional teaching materials for the control class. Based on the reality, the students only learn from the text book and learning in the class. They are less active to discuss. It is because the book is not interesting from them. The students got the vocabulary only from the conventional which is given from the lecture. Then, there are many students in control class got lower score than in experimental class.

In the other side, the students in experimental class are active in learning process when the teacher gives the treatment using Authentic Reading Materials. The Authentic Reading Materials gave some advantages for the students. The students are interested in studying because the Authentic Reading Materials provide the real language as the native. The students got the vocabulary from many sources. The researcher applied Authentic Reading Materials. So, the students are exposed to real discourse and they are getting the new vocabulary from the Authentic Reading Materials. The students have a positive effect on learner motivation. They always do the assignment from the teacher. the students is easier to understand and imitate the vocabulary from the video internet and e learning as Authentic Reading Materials. In the classroom, the students are active to ask and discuss about the new vocabulary because Authentic Reading Materials provide exposure to real language and continuously updated. So, Authencic Materials can enrich the students' vocabulary.

It was supported with the statement about the advantages of Authentic Reading Materials from Sanderson said that it is appropriately exploited, is significant for many reasons, for example students are exposed to real discourse, as in videos of interviews with famous people where intermediate students listen for gist. Authentic Reading Materials keep students informed about what is happening in the world, so they have an intrinsic educational value (Ahmad, 2019).

In the conclusion, this research prove that that there is the effectiveness of using Authentic Reading Materials toward the students' reading comprehension mastery at the sixth grade of University of Nahdlatul Ulama Lampung and Authentic Reading Materials is more effective than the conventional teaching materials toward the students' reading comprehension mastery at the sixth grade of University of Nahdlatul Ulama Lampung. 


\section{CONCLUSION}

Based on the findings and discussion, the researcher concluded that the use of Authentic Reading Materials is effective toward the students' reading comprehension mastery at the sixth grade English Education Department of Nahdlatul Ulama Lampung University. The researcher finds that tratio is 4,61. Moreover the researcher looks at ttable for $\alpha=1 \%$ is 2,66 and for $a=5 \%$ is 2,00 . It means that tratio $>$ ttable. So, Ho is rejected and Ha is accepted.

The suggestion as follows:

For The Teacher: English teacher should select the update materials especially for teaching reading comprehension. Bringing the real life examples in teaching learning process such as Authentic Reading Materials can help the students easier in mastering reading comprehension.

For the students: The students can use Authentic Reading Materials in their learning. Therefore, they are able to learn the real reading text.

For the other research: Other researcher should read and comprehend the research that taken before it is used as a reference in research. Therefore, the researcher can decide whether the research is able to be guidance in the research or not. In addition, the other researcher should make the research better than the previous research

\section{REFERENCES}

Ahmad, S. Z. (2019). Digital Posters to Engage EFL Students and Develop Their Reading Comprehension. Journal of Education and Learning, 8(4), 169. https://doi.org/10.5539/jel.v8n4p169

Dhilon, bobby pramjit singh. herman. syafryadin. (2020). the Effect of Skimming Method To Improve Students ' Ability in Reading Comprehension on Narrative Text. 2069(6), 77-88.

Dilek Belet Boyaci, S., \& Güner, M. (2018). The impact of authentic material use on development of the reading comprehension, writing skills and motivation in language course. International Journal of Instruction, 11(2), 351-368. https:// doi.org/10.12973/iji.2018.11224a

Enggar Wigawati Wibowo, Y., Syafrizal, \& Syafryadin. (2020). An Analysis of

English Teacher' Strategy In Teaching Reading Comprehension. 4(1).

https:/ /jurnal.unigal.ac.id

Haerazi, H., Prayati, Z., \& Vikasari, R. M. (2019). Practicing Contextual Teaching and Learning (Ctl) Approach To Improve Students $\square$ Reading Comprehension in Relation To Motivation. English Review: Journal of English Education, 8(1), 139. https:/ / doi.org/10.25134/erjee.v8i1.2011

Handayani, N. D., Mantra, I. B. N., \& Suwandi, I. N. (2019). Integrating 
collaborative learning in cyclic learning sessions to promote students' reading comprehension and critical thinking. International Research Journal of Management, IT and Social Sciences, 6(5), 303-308.

https:/ / doi.org/10.21744/irjmis.v6n5.777

Ibrahim Magableh, I. S., \& Abdullah, A. (2020). Effectiveness of differentiated instruction on primary school students' English reading comprehension achievement. International Journal of Learning, Teaching and Educational Research, 19(3), 20-35. https:// doi.org/10.26803/ijlter.19.3.2

Locher, F., \& Pfost, M. (2020). The relation between time spent reading and reading comprehension throughout the life course. Journal of Research in Reading, 43(1), 57-77. https:/ / doi.org/10.1111/1467-9817.12289

Martina, F., Rakhmanina, L., \& Juwita, S. (2020). the Effect of Time Constraint on Student Reading Comprehension Test Performance in Narrative Text. JOLLT Journal of Languages and Language Teaching, 8(3), 323-329.

Rusmawaty, D., Atmowardoyo, H., Hamra, A., \& Noni, N. (2018). Teachers' Beliefs of Authentic Materials for Teaching Reading in Indonesian EFL Classrooms. Journal of Language Teaching and Research, 9(3), 608. https:/ / doi.org/10.17507/jltr.0903.21

Sukmawan, S., \& Setyowati, L. (2019). Authentic Reading Materials in Storybirds for Reading to Write: The Students' Voices. January. https:/ / doi.org/10.4108/eai.23-3-2019.2284954

Syafrizal, S., Masrupi, M., \& Mauludah, I. (2019). The impact of experiential learning method and vocabulary mastery toward indonesian students' reading comprehension through animation video. Journal for the Education of Gifted Young Scientists, 7(3), 449-458.

https://doi.org/10.17478/jegys.531412

Yani, A., Mangkunegara, A. A. A. P., Revisi, P. K. E., \& Aditama, R. dan S. (2011). Metode Penelitian Kuantitatif Kualitatif dan RED. Alfabeta.

Copyright Holder :

(C) Diyah Dwi Agustina, Adelina Anum (2020).

First Publication Right :

( ) Journal of English Development (JED)

This article is under: 